\title{
PENGEMBANGAN BUDIDAYA PORANG DI LAHAN \\ BAWAH TEGAKAN POHON DI DESA PACAREJO, KECAMATAN SEMANU, KABUPATEN GUNUNGKIDUL
}

\author{
Sumarwoto Ps' ${ }^{1}$, Oktavia S. Padmini ${ }^{2}$, dan Dwi Aulia Puspitaningrum3 \\ ${ }^{12}$ Staf PengajarJurusan Agroteknologi Fakultas Pertanian UPN Veteran Yogyakarta \\ 3Staf PengajarJurusan Agribisnis Fakultas Pertanian UPN Veteran Yogyakarta \\ ${ }^{1}$ Email address sumarwoto.ps@gmail.com
}

\begin{abstract}
Pacarejo Village in Semanu District Gunung Kidul Regency is a village where is still a lots of potential lands under Tree forest stands. Land Proverties taht belonging of Universitas Pembangunan Nasional Veteran Yogyakarta (UPNVYK) located in this place. It is available to cultivate Porang stalk. Porang is going to growing well, if there are shading plants, in the form of stands.There are still capable of about 50 percent light. The land in Pacarejo Village is overgrown with teak, sonokeling, mahony and sengon trees. It is rich and get benefits apart from the timber, soo the land underneath can be used for plant that can provide yields well. In other hand, this activities provide economic added value to the community around the forest and get the better welfare. This Community servises activity aims to cultivate land, including UPNVYK land which has not been utilized as well as to be used as a forum for education for the community and can obtain additional results, thereby improving the local community's economy. The program dedicated to improve the commnunity empowerment. In program implementation, we conduct with communities approach methode. It was carried out using the RRA (Rapid Rural Approach) and PRA (Participatory Rural Approach) methods, which are the philosophy model to close the village community deeply. All of Activities have been doing by Focus Group Discussion (FGD), get the extention to the community, dissemination commodities of Porang and its benefits of commodities. The program are cultivate land with Porang and make the derivative product after harvest handling. To get the ideal of the program, to be done through scheduled mentoring, implementation of technology, controlling and monitoring. The application of the method, in the form of activities by presenting a "demplot" of Porang cultivation and assistance properly and correctly. It is able to carry out the cultivated of post-harvest handling and calculated revenue to be get economical benefit. The results of the activities showed that the program is useful and able to get the land use optimal and the end of the program will increase household community income.
\end{abstract}

Keywords: Cultivation, Porang, Tree stands, Empowerment, Income

Abstrak
Desa Pacarejo, Kecamatan Semanu, Kabupaten Gunung Kidul merupakan
desa yang di dalamnya masih banyak tersedia lahan potensial di bawah


tegakan pohon, termasuk di dalamnya lahan milik UPNVY sehigga berpeluang untuk pengembangan Porang. Porang bagus pertumbuhannya jika ada tanaman pelindung, berupa tegakan yang masih mampu meneruskan cahaya sekitar 50 persen. Desa Pacarejo lahannya banyak ditumbuhi tegakan pohon jati, sonokeling, mahoni dan sengon. Kondisi seperti ini, diharapkan masih tetap memberikan manfaat selain hasil kayunya, lahan di bawahnya dapat dimanfaatkan untuk tanaman yang dapat memberikan potensi hasil sehingga dapat memberikan nilai tambah ekonomi bagi masyarakatnya. Kegiatan ini bertujuan untuk mengoptimalkan pemanfaatan lahan, termasuk lahan UPN yang belum dimanfaatkan yang sekaligus dapat digunakan sebagai ajang edukasi bagi masyarakat dan dapat meperoleh hasil tambahan, sehingga meningkatkan ekonomi masyarakat setempat. Dalam pelaksanaan program ini, dilakukan pendekatan dengan menggunakan metode RRA (Rapid Rural Appresial) dan PRA (Partisipatori Rural Approach), yang merupakan metode pendekatan yang filosofinya dikenal untuk memahami desa secara cepat. Dilaksanakan dengan cara Focus Group Discussion (FGD), edukasi kepada masyarakat, sosialisasi komoditas, manfaat komoditas dan cara budidaya serta penanganan pasca panen. Agar berhasil, perlu dilakukan melalui pendampingan yang diakhiri dengan evaluasi dan monitoring secara terjadwal. Penerapan metode, berupa kegiatan dengan pemberian "demplot" budidaya porang dan pendampingan secara baik dan benar, sehingga kelak dapat melakukan budidaya sekaligus penanganan pasca panen serta perhitungan usaha tani dengan baik dan benar. Hasil kegiatan diharapkan dapat bermanfaat dan mampu mengoptimalkan penggunaan lahan dan peningkatan pendapatan masyarakat.

Kata Kunci: Budidaya, Porang, Tegakan pohon, Pemberdayaan, Pendapatan

\section{PENDAHULUAN}

Desa Pacarejo merupakan desa hasil penggabungan dari 3 Kelurahan yaitu, Kelurahan Kuwangen, Kelurahan Kuwon dan Kelurahan Dengok, dengan 28 pedukuhan. Desa Pacarejo, dari Kota Wonosari berjarak sekitar $7 \mathrm{~km}$, memiliki luas wilayah kurang lebih 3693.1810 ha yang berbatasan langsung dengan desa-desa lain di Kecamatan Semanu dan juga Kecamatan lain di Kabupaten Gunungkidul (BPS, 2019). Desa Pacarejo memiliki 13 telaga untuk menampung air hujan, yang memiliki daya tampung maksimal kurang lebih $60.000 \mathrm{~m} 3$. Jenis tanah pada umumnya adalah komplek latosol dan mediteran merah dengan bebatuan cadas, sedangkan bentuk wilayahnya bergelombang sampai berbukit. Suhu udara di Desa Pacarejo rata-rata dari suhu $23,2^{\circ} \mathrm{C}$ sampai $32,4^{\circ} \mathrm{C}$ dengan kelembaban $80 \%$ sampai $85 \%$. Kondisi seperti ini, masih memungkinkan untuk mengefektifkan penggunaannya dengan memilih komoditas yang tepat, seperti porang atau jenis empon-empon lainnya. 
Di dalam desa ini terdapat lahan tegakan jati, sonokeling dan mahoni dan sengon, semua tegakan ini berpeluang baik sebagai tanaman pelindung bagi Porang (Sumarwoto dan Priyanto, 2020). Kondisi saat ini, semua lahan termasuk milik UPNVY belum produktif, belum dimanfaatkan dengan baik. Untuk itu perlu adanya ide dan gagasan untuk memanfaatkan dengan baik, sekaligus dapat bermanfaat bagi masyarakat Pacarejo.

Pertumbuhan perekonomian masyarakat Desa Pacarejo yaitu pertanian, perdagangan, peternakan dan beberapa sektor lainnya. Namun mayoritas pertanian yang menjadi mata pencahariannya. Jumlah penduduk dari 28 pedukuhan yang ada di Desa Pacarejo kurang lebih 19.000-an penduduk, dengan tingkat pendidikan masyarakat yang masih rendah.

Potensi desa, berupa sumberdaya alam dengan: (a) Lahan pertanian yang kering tadah hujan yang tergantung pada iklim, khususnya curah hujan, hutan yang ada merupakan hutan swadaya masyarakat dengan tanaman jati, mahoni, sonokeling, sengon, dan lainlain; (b) Flora dan fauna yang ada antara lain, berupa tanaman musiman seperti padi ladang, palawija (jagung, kacang tanah, kedelai, ubi kayu, dan lain-lain). Sedangkan tanaman tahunan meliputi, buah-buahan (srikaya, mete, mlinjo, nangka, mangga, kelapa, dan jeruk) dan kayu-kayuan (jati, mahoni, bambu). Fauna yang sampai saat ini masih nampak di Desa Pacarejo antara lain berupa berbagai jenis burung lokal, harimau kumbang, harimau cecep, ular, musang, landak, ayam, kera ekor panjang. Lalu fauna air antara lain perikanan telaga, sungai, kolam; (c) Industri yang sebagian besar industri rumah tangga dan usaha industri kecil. Sumberdaya alam yang terakhir yaitu (d) pariwisata. Pariwisata yang dapat dikembangkan yaitu wisata budaya, dimana Desa Pacarejo memiliki berbagai potensi seni budaya yang saat ini masih tumbuh dan berkembang dengan pesat, diiringi dengan pembinaan rutin dan baik oleh pemerintah maupun swasta. Tidak hanya seni budayanya saja, pariwisata yang dapat dikunjungi di Desa Pacarejo yaitu Telaga Jonge, Kali Suci, Gua Jomblang, dan Candi Dengok.

Desa Pacarejo memiliki motto Aman, Bersatu, Edukatif, Religius; dengan visi "Memetri Lestarining Katentreman Pacarejo"; dan misinya adalah: (a) Meningkatkan pendapatan masyarakat dan membuka peluang kerja untuk mengurangi pengangguran, dengan mendorong masyarakat menciptakan pekerjaan untuk dirinya 
sendiri; (b) Pengelolaan kebudayaan masyarakat menjadi wisata budaya; (c) Pengembangan dan peningkatan kualitas sumber daya manusia aparatur desa, lembaga desa, dan masyarakat; (d) Meningkatkan penyediaan sarana prasarana infratruktur desa; (e) Meningkatkan penguatan BUMDes; (f) Meningkatkan partisipasi masyarakat dalam pemerintah, pembangunan, pembinaan sosial kemasyarakatan dan pemberdayaan masyarakat.

Permasalahan yang dihadapi masyarakat desa Pacarejo yang menjadi objek pengembangan budidaya porang adalah sebagai berikut: masyarakat desa Pacarejo sebagian besar belum mengenal tentang komoditas Porang, apalagi dalam hal budidaya pengembangannya. Sementara melalui media TV dan media sosial lainnya, masyarakat mendengar bahwa prospek porang sangat menjanjikan, sebagaimana dialami oleh seorang Paidi yang tadinya sebagai seorang pemulung saat ini dapat menjadi seorang eksportir porang dan menjadi milyarder. Di samping itu lahan yang ada di wilayah desa Pacarejo yang luasnya mencapai ribuan hektar dan sebagian kecil milik UPN "Veteran" Yogyakarta yang merupakan calon pengembangan kampus, namun belum dikelola apalagi dimanfaatkan untuk kepentingan civitas akademika. Untuk itu melalui pertimbangan Tim Pengabdi, adanya sesuatu asset yang tidak segera dimanfaatkan akan menjadi sia-sia, dan perlu dimanfaatkan segera.

Tujuan kegiatan program ini adalah untuk: (1) mengenalkan komoditas yang saat ini mempunyai prospek yang sangat menjanjikan.; (2) memberikan edukasi kepada masyarakat sekitar calon kampus tentang segala sesuatu yang berkaitan dengan Porang (cara budidaya, manfaatnya, penanganan pasca panen, dan pemasarannya); (3) memberikan transfer keterampilan teknologi budidaya yang sederhana dan mudah dilakukan petani, tetapi intensif; (4) memberikan transfer ketrampilan dalam penanganan pasca panen baik yang sederhana mapun yang modern; (5) menumbuhkembangkan jiwa kewirausahaan bagi kelompok masyarakat secara mandiri dalam pertanian berkelanjutan tanaman Porang.

Manfaat dan luaran kegiatan program Pengabdian bagi Masyarakat $(\mathrm{PbM})$ ini adalah agar masyarakat Desa ini dapat mengenal dan paham tentang Porang mulai dari hulu sampai hilir (cara budidaya porang mulai dari persiapan pembibitan, persiapan lahan tanam, cara pemeliharaan, cara panen dan pasca panen; pengembangan pertanian 
berkelanjutan melalui penggunaan bahan organik (pupuk dasar, pupuk organic cair, pestisida organic) (Deptan,2002); meningkatkan pengetahuan, social dan ekonomi masyarakat; pada akhirnya akan mengangkat kemajuan desa Pacarejo.

\section{METODE DAN PELAKSANAAN}

Metode pendekatan yang digunakan dalam kegiatan $\mathrm{PbM}$ ini adalah metode RRA (Rapid Rural Appresial)/PRA (Partisipatori Rural Appresial). RRA dan $P R A$ adalah falsafah, pendekatan metode yang dikenal sebagai memahami desa objek kegiatan secara cepat, dengan prinsip-prinnsip yang dipakai: belajar secara cepat dan progresif, melalui eksplorasi yang terencana, pemakaian metode yang fleksibel, improvisasi, pengulangan serta menyesuaikan dengan proses belajar atau pemahaman, (2) optimalisasi pertukaran, mengkaitkan biaya pemahaman dengan informasi yang benar-benar bermanfaat bagi masyarakat di desa Pacarejo, dengan pertukaran antar kuantitas, kegayutan, keakuratan serta ketepatan waktu, (3) pemberian fasilitas, artinya memberikan fasilitas penyelidikan, analisis, penyajian dan pemahaman oleh masyarakat di wilayah desa Pacarejo, sehingga mereka dapat menyajikan dan memiliki hasilnya, serta mempelajarinya, (4) kesadaran dan tanggung jawab diri yang kritis, artinya fasilitator secara terus-menerus menguji tingkah laku mereka dan mencoba melakukannya secara lebih baik, (5) saling berbagi informasi dan gagasan antar masyarakat di desa Pacarejo dengan fasilitator, dan antar fasilitator yang berbeda, serta saling berbagi wilayah kegiatan, pelatihan dan pengalaman antar organisasi yang berbeda. Kegiatan - kegiatan di atas direncanakan dan dilakukan melalui Focus Group Discussion (FGD), pelatihan, pendampingan dan diakhiri dengan evaluasi dan monitoring (Anonim, 2006).

\section{Pelaksanaan Kegiatan}

Pelaksanaan kegiatan dilakukan melalui beberapa tahap dan pertemuan, yang di adakan di Balai dusun yang ada di wilayah desa Pacarejo dan juga di rumah ketua Kelompok Tani atau pemuka masyarakat yang kondisi rumahnya memungkinkan untuk pertemuan. Waktu pelaksanaan biasanya disesuaikan dengan kesepakatan dan keadan waktu luang warga masyarakat. Biasanya yang dilakukan adalah setiap hari sabtu atau minggu pada saat petani sudah pulang dari kerja di lahan sawahnya sekitar jam 15.30 wib. Jumlah peserta setiap pertemuan sekitar 30-50 orang, sesuai dengan tingkat kepentingan 
atau materi yang disampaikan. Dalam rangka pengenalan di awali dari perwakilan masing-masing kelompok tani yang ada di Desa tersebut, dengan tingkat pendidikan yang bervariasi mulai dari tingkat sekolah dasar sampai dengan yang perguruan tinggi.

\section{HASIL DAN PEMBAHASAN}

Desa Pacarejo terletak kurang lebih $7 \mathrm{~km}$ disebelah tenggara Kota Wonosari (Ibukota Kabupaten Gunungkidul). Masyarakat taninya sangat antusias dan berpotensi untuk pengembangan budidaya tanaman porang ini. Untuk keberhasilan program dilakukan tahapan sebagai berikut:

\section{Tahap Sosialisasi}

Dalam kegiatan $\mathrm{PbM}$ ini diawali dengan perkenalan dan sosialisasi kepada masyarakat setempat, tentang segala sesuatu yang berhubungan dengan porang mulai dari hulu sampai dengan hilir kepada perwakilan para kelompok tani, pemuka masyarakat dan ibu-ibu PKK setempat. Misalnya dalam membedakan antara porang dengan jenis iles-iles lain yang masih dalam satu famili.

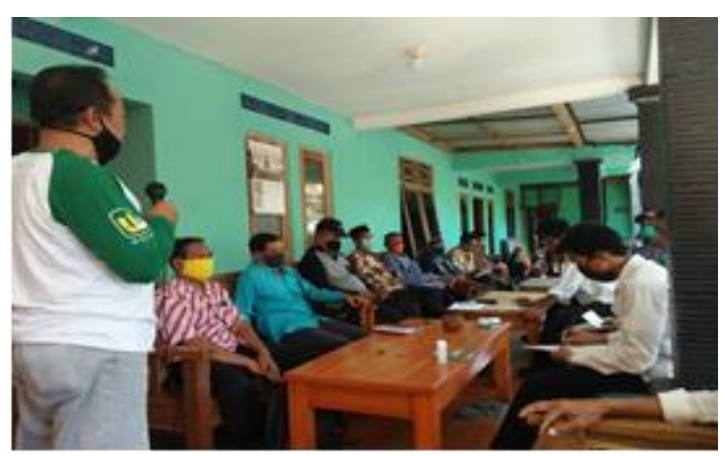

Gambar 1 a. Saat Sosialisasi ke 1

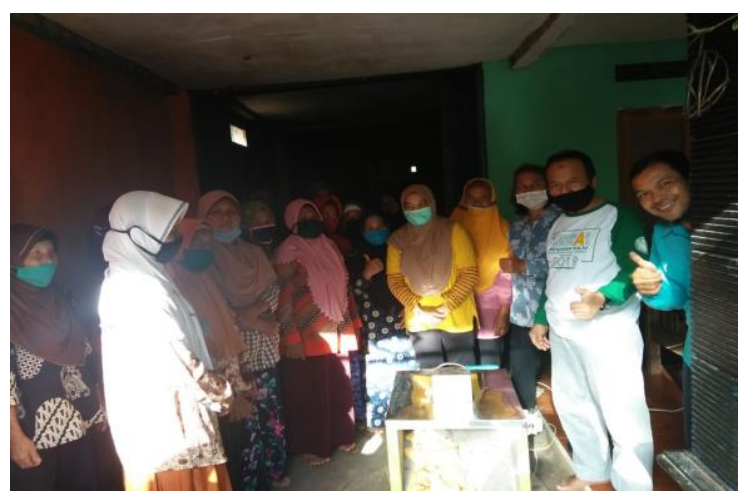

Gambar 1 b. Saat Sosialisasi ke 2

Dalam tahapan ini, dijelaskan secara detail mengenai cara membedakan jenis tanaman porang dengan jenis tanaman yang mirip dan masih satu famili (suweg, iles-iles putih dan walur atau badur). Bahkan termasuk kandungan yang ada di dalam umbi tersebut, serta manfaatnya dalam industri, maupun bagi pangan fungsional. 


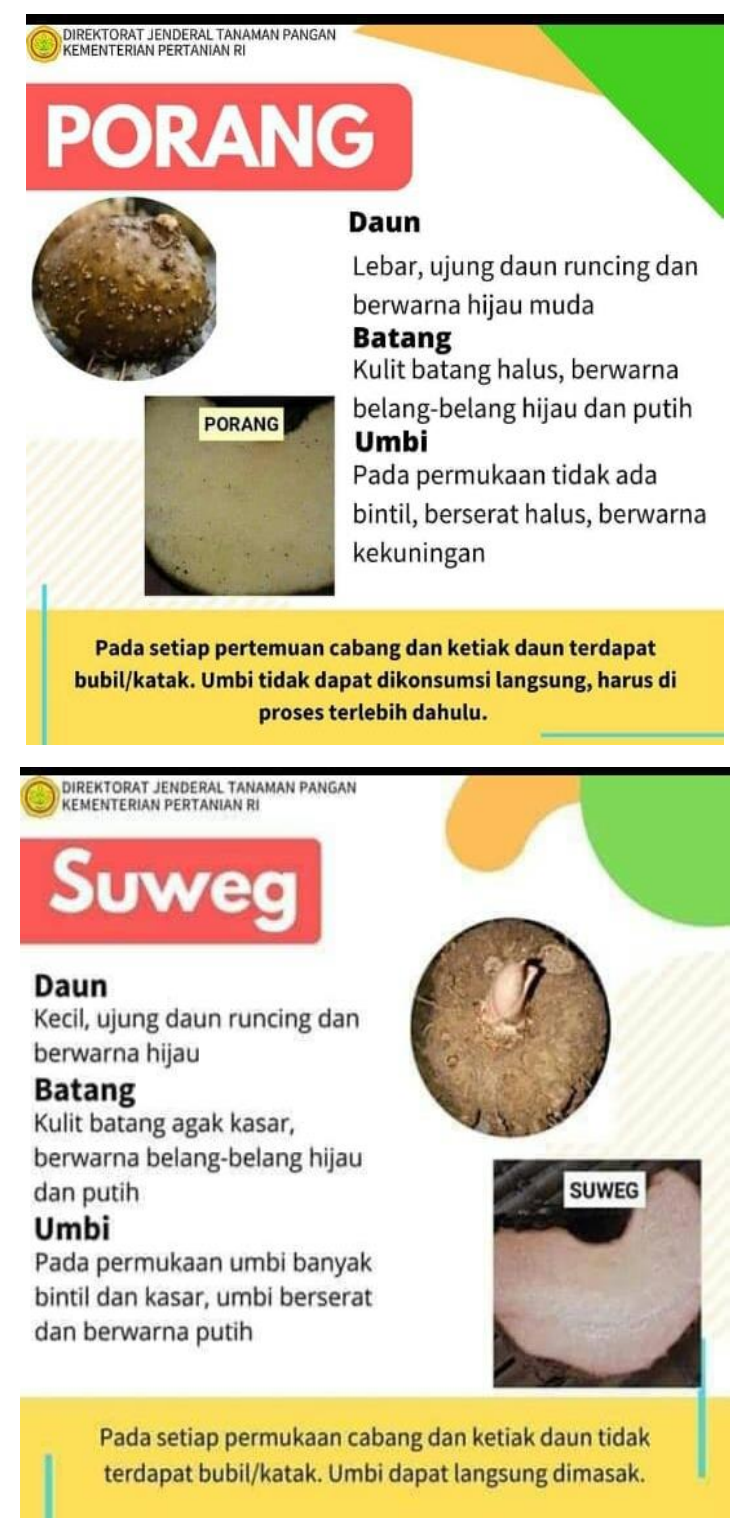

(2) DIREKTORAT JENDERAL TANAMAN PANGAN
KEMENTERIAN PERTANIAN RI

\section{lles-iles putih}

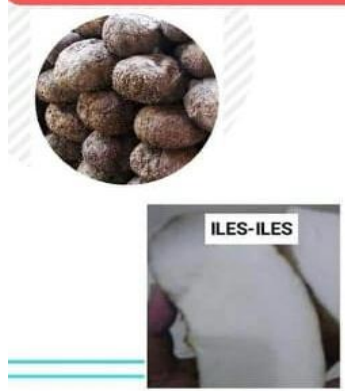

\section{Daun}

Kecil, ujung daun runcing dan berwarna hijau tua

\section{Batang}

Kulit batang halus, berwarna

keunguan dan bercak putih

Umbi

Pada permukaan umbi

terdapat bintil, umbi berserat

halus dan berwarna putih

seperti bengkoang

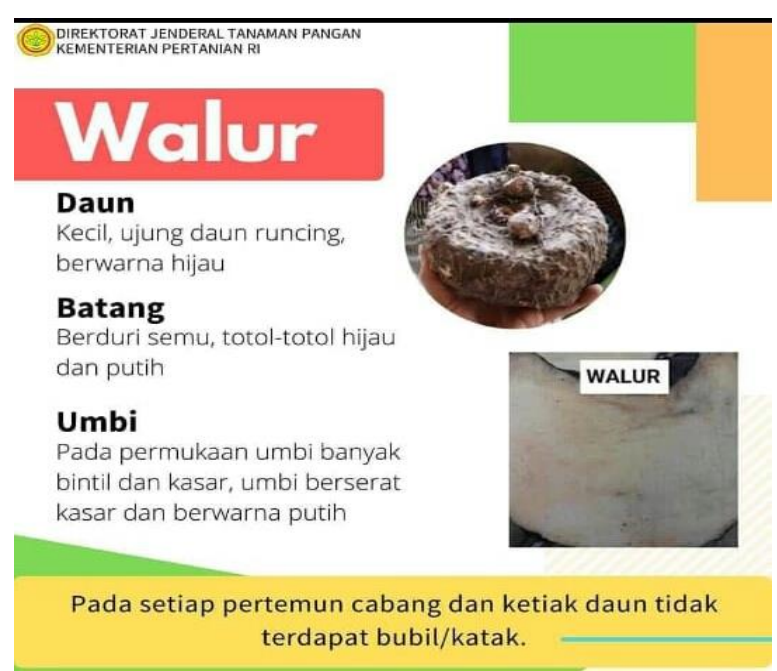

Dari beberapa gambar di atas, masyarakat lebih mudah membedakan antara porang dengan jenis tanaman iles-iles lainnya, sehingga pada saat akan mengkonsumsi maupun usaha yang lain, terbaik yang lain.

Berdasarkan hasil pembicaraan dengan mitra kelompok tani desa Pacarejo, sangat terbuka peluang untuk memecahkan permasalahan bersama antara Kelompok Tani yang ada di Desa Pacarejo dengan Tim Pengabdi dari UPN "Veteran" Yogyakarta dalam rangka mengoptimalkan pemanfaatan lahan di bawah tegakan pohon yang ada di desa Pacarejo. Pengembangan porang di bawah tegakan pohon diawali dengan sosialisasi budidaya porang dan penanganan hasil panen (pasca panen awal porang) kepada para pemuka masyarakat dan perwakilan kelompokkelompok tani ataupun PKK setempat. 

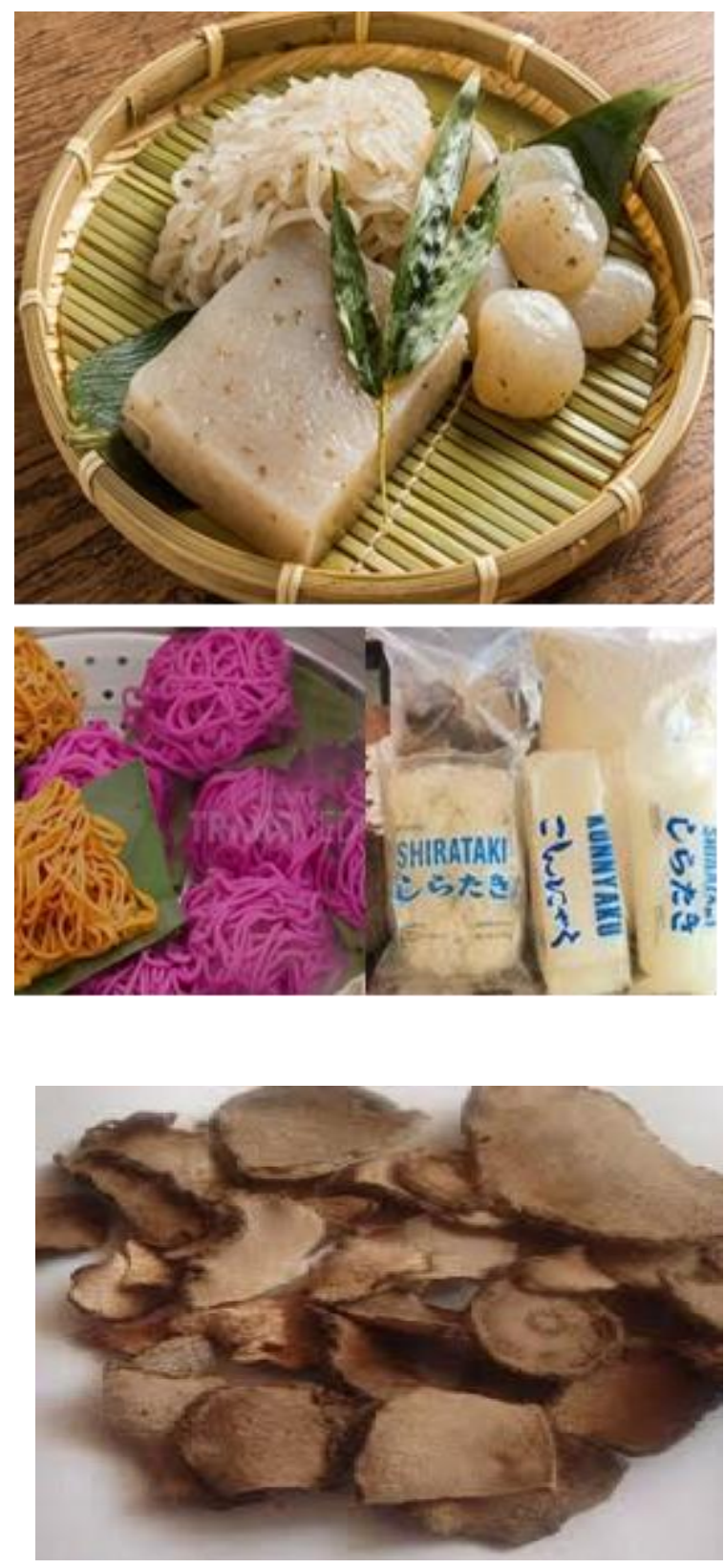

Gambar 2: Berbagai produk makanan dan Chips dari Porang

Gambar 2 di atas adalah contoh sebagian produk manfaat porang bagi keperluan pangan fungsional, dan chips porang. Chips saat ini sebagai produk eksport setelah umbi basah diiris tebal 5-7 mm, kemudian dikeringkan sampai kadar air sekitar 11\%. Adapun produk untuk industri dan kesehatan sebenarnya masih cukup banyak, misalnya untuk industri pesawat, industri kertas, industri obat, dll.

Sosialisasi pengenalan porang dan prospek pengembangan porang diawali dengan adanya berita TV swasta sebagaimana dilakukan oleh seorang mantan pemulung bernama PAIDI yang tinggal di Kediri Jawa Timur. Konon saat ini yang bersangkutan telah menjadi milyarder berkat tanaman Porang yang dibudidayakannya. Namun menyadari bahwa masyarakat sampai saat ini, banyak yang belum tahu apa itu porang, gunanya untuk apa, bagaimana cara budidaya dan tanamnya. Berdasarkan uraian di atas, sangat terbuka peluang untuk memecahkan permasalahan bersama antara Kelompok Tani Pacarejo dengan Institusi UPN "Veteran" sebagai pemilik lahan yang sampai saat ini belum produktif dan belum tahu bagaimana dapat mengoptimalkan pemanfaatannya bagi para mahasiswa, tenaga kependidikan atau dosennya dan juga bagi masyarakat sekitar lahan tegakan pohon yang ada di desa tersebut.

\section{Tahap Budidaya}

Dalam budidaya kali ini tidak berjalan seperti biasanya karena sangat terbatas waktunya, sehingga dengan terpaksa dilakukan percepatan tanam dengan cara melakukan penanaman dan pemeliharaan tanaman lewat polibag terlebih dahulu. Namun ada keuntungan 
yang dapat diperoleh masyarakat, terutama dalam hal transfer teknologi budidaya khususnya dalam perbanyakan bahan tanam. Dalam perbanyakan kali ini dilakukan tidak seperti biasanya, karena dilakukan dengan cara pembelahan umbi utama atau umbi "katak" untuk mengatasi akibat mahalnya benih dari katak maupun umbi bahan tanam.

Untuk persiapan media polibag, diperlukan bahan untuk media tanam berupa arang sekam, pupuk kandang dan tanah yang memenuhi syarat sebagai media tanam dengan perbandingan 1:1:1 (v/v). Apabila "katak" telah tumbuh, setiap 10-14 hari sekali, perlu dipupuk dengan menggunakan POC urin kelinci yang sudah terfermentasi, sebagai langkah menuju pertanian organik. Setelah hujan datang dan terjadi secara rutin, tanaman baru dipindah ke lahan.

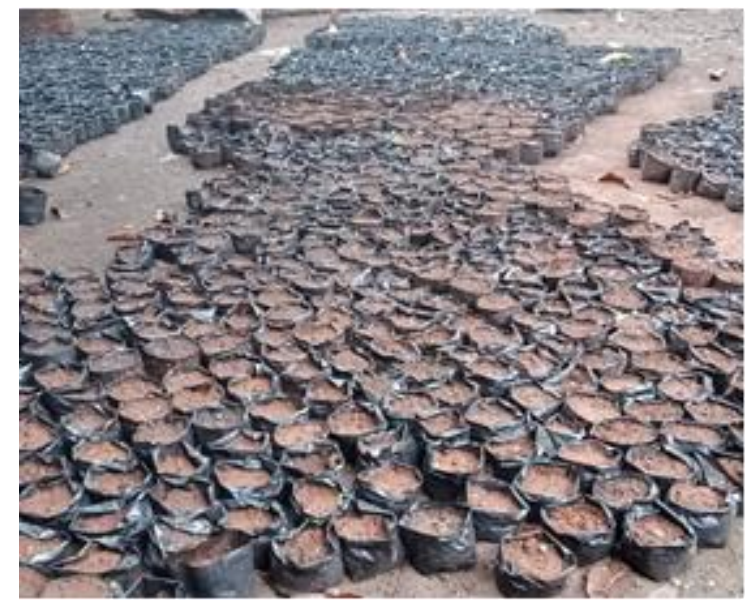

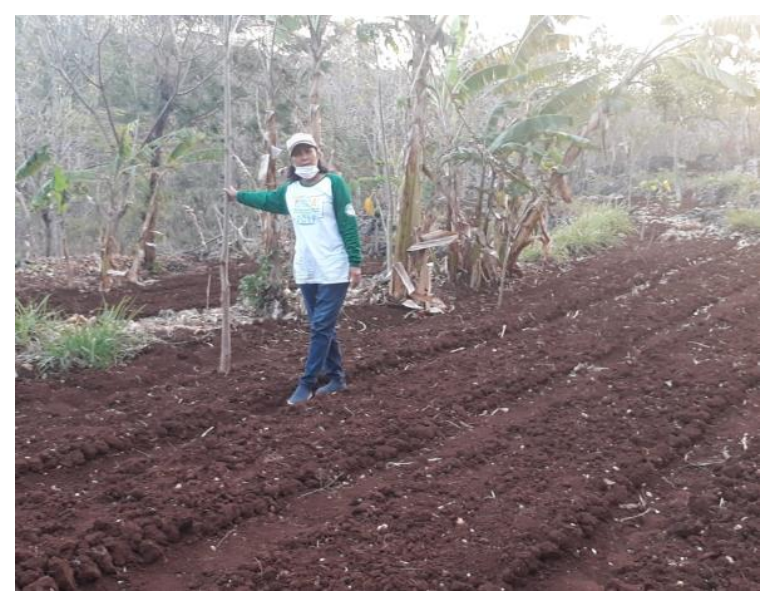

Gambar 4: Tapak demplot Porang Bibit yang akan ditanam berupa bulbil atau "katak", mengingat saat ini harganya sangat mahal maka dilakukan persiapan bibit melalui perbanyakan dengan teknologi pembelahan dan perendaman dengan menggunakan Zat Pengatur Tumbuh (ZPT). Bulbil yang telah dibelah, kemudian direndam paling minimal 12 jam terlebih dahulu. Selanjutnya ditiriskan dan dikering anginkan, apabila sudah kering kemudian disimpan disebuah tupper ware atau kantong plastik kedap udara.

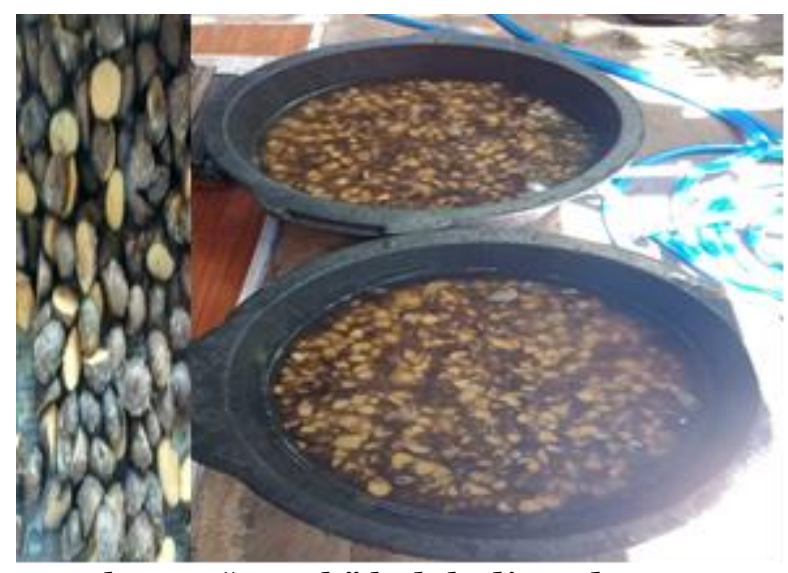

Gambar 5. "Katak" belah direndam ZPT 


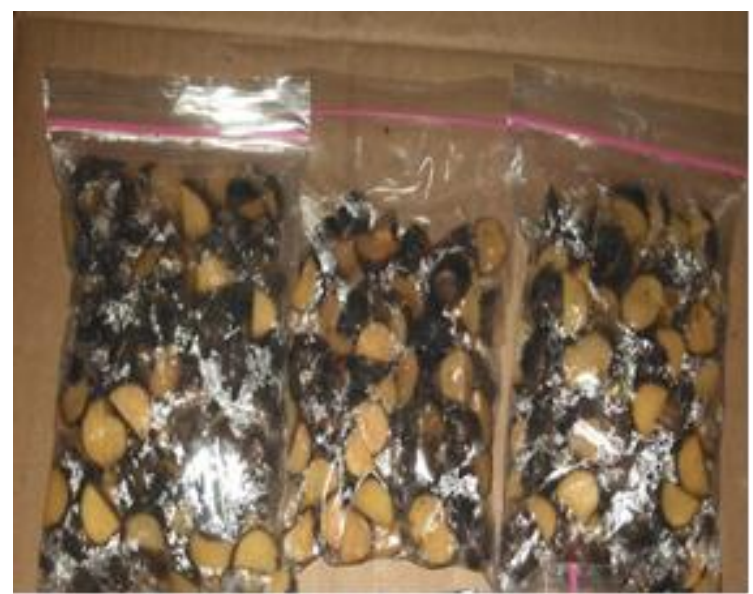

Gambar 6. "Katak" belah dalam kantong plastik kedap udara

Penyimpanan dilakukan selama 35 hari, dan diakhiri ditandai dengan pecahnya mata tunas (munculnya tunas) di permukaan kulit bulbil dan dilanjutkan dengan penanaman ke polibag yang telah disiapkan sebelumnya. Jika nanti telah tumbuh, baru dilakukan pemindahan ke lahan tanam dengan cara diputar.

\section{PENUTUP}

\section{Simpulan}

Hasil yang dicapai dalam pelaksanaan kegiatan pengembangan budidaya porang di desa Pacarejo, masih sangat terbatas mengingat musim tanam porang yang sebenarnya baru bisa dilakukan apabila hujan sudah mulai turun secara rutin. Hujan secara rutin, sepertinya baru akan terjadi sekitar awal bulan November. Untuk itu yang dapat dilakukan oleh Tim adalah berupa persiapan lahan dan persiapan tanam dengan menggunakan berbagai cara perbanykan bahan tanam. Persiapan tanam yang sudah dapat dilakukan adalah berupa persiapan lahan, dimana lahan telah siap dibuat bedengan kecil memanjang yang telah digemburkan dan disertai dengan saluran drainase secukupnya. Persiapan bibit, dilakukan menggunakan perbanyakan belah "katak" menjadi beberapa bagian tergantung besar kecilnya "katak". Pada akhirnya diharapkan melalui kegiatan program pengabdian ini, terwujud adanya transfer tenologi dalam budidaya porang, dan gerakan pengembangan budidaya porang di desa Pacarejo serta desa sekitarnya dengan lancar melalui mencuri start tanam dengan menggunakan media polibag. Diharapkan dengan mencuri start budidaya ini kelak dapat melakukan tanam awal dan pindah tanam ke lahan sudah berupa bibit yang tumbuh cukup besar melalui cara putar dari media yang digunakan. Dengan metode budidaya curi start ini, diharapkan kelak dapat memperoleh pertumbuhan tanaman lebih lama waktu tumbuh vegetatifnya, sehingga dapat membentuk umbi lebih besar. Disamping itu kelak dapat memanfaatkan lahan-lahan yang potensial untuk dioptimalkan penggunaannya, sehinga kelak dapat meningkatkan kesejahteraaan masyarakat setempat, namun juga tidak 
boleh terlena ke depan, karena masih cukup banyak tantangan yang masih harus dihadapi dan diatasi seperti; sistem pemasaran dan kelembagaan yang masih belum cukup kuat, masyarakat masih berorientasi pada produksi pertanian dan belum paham pentingnya pada orientasi industri jasa di Semanu Gunung Kidul.

\section{Ucapan Terima Kasih}

Terimakasih disampaikan kepada Ketua dan Staf LPPM UPN "Veteran" Yogyakarta yang telah banyak membantu dalam pendanaan dan penyelesaian administrasi. Demikian juga ucapan terima kasih disampaikan kepada Bapak Kardiman, dan keluarga yang telah banyak membantu di dalam pelaksanaan kegiatan di lapang dan pengembangan budidaya porang sebagai wujud nyata dalam pengabdian kepada masyarakat di desa Pacarejo.

\section{DAFTAR PUSTAKA}

Anonim, 2006. Panduan Pengambilan Data dengan Metode Rapid Rural Appraisal (RRA) dan Participatory Rural Appraisal (PRA), Vol 2. Kerjasama antara Program Rehabilitasi dan Pemulihan Cadangan Sumberdaya Alam Satker Rehabilitasi dan Pengelollan Terumbu Karang (COREMAP II) dengan Direktorat Jenderal Kelautan, Pesisir dan Pulau-pulau
Kecil Departemen Kelautan dan Perikanan, dan PT. Bina Marina Nusantara (Konsultan Kelautan dan Perikanan) Kantor: Gedung Sarana Pengembangan Usaha Lt.8, Jl. Angkasa Blok B-9 Kav 6 Kota Baru, Bandar Kemayoran, Jakarta 10720 Telp. (021) 6546630, Fax. (021) 6546631, E-mail: binamarina @cbn.net.id

BPS, 2019. Kabupaten Gunung kidul dalam Angka. Badan Pusat Statistik Kabupaten Gunung Kidul, Daerah Istimewa Yogyakarta, Indonesia.

Deptan, 2002. Pertanian organik.

Departemen Pertanian RI, Jakarta.

Sumarwoto dan Priyanto, S., 2020. Tenik Budidaya dan Ciri Iles-iles Kuning (Amorphophallus muelleri Blume) "Porang". Penerbit LPPM UPN "Veteran" Yogyakarta.

Suwandi, 2018. Perbedaan tanaman Porang dengan jenis Iles-iles lain. Direktorat Jendral Tanaman Pangan Kementrian Pertanian Republik Indonesia, Jakarta. 